 \\ z Filologii Polskiej i Słowiańskiej
}

\section{Rec.: Anna Niepytalska-Osiecka, Socjolekt polskich alpinistów. Analiza leksykalno-semantyczna słownictwa, Wydawnictwo LIBRON - Filip Lohner, Kraków 2014, ss. 286}

Każdy język jest niezwykle eklektycznym narzędziem komunikacji, obfitującym w rozmaite style i odmiany. Współcześnie chyba najbogatszą grupę stanowią socjolekty, których na przestrzeni wieków wykształciło się wiele również na polskim gruncie. Trudno podać dokładną ich liczbę, gdyż lingwiści przekonują, że każda grupa społeczna spojona silnymi więzami, mająca wspólne potrzeby komunikacyjne może skonstruować swoisty kod na bazie języka ogólnego. Pomimo takich tez zachęcających językoznawców do poszukiwania nowych pól naukowej eksploracji na rynku wydawniczym nie pojawia się zbyt wiele prac poświęconych niezbadanym dotychczas socjolektom. O ile w tomach wieloautorskich znajdziemy szkice o wybranych aspektach profesjolektu informatyków czy slangu homoseksualistów, o tyle brakuje monograficznych opisów tego typu odmian. W takich okolicznościach z uznaniem i uwagą należy podchodzić do syntetycznych ujęć zarówno istniejących od dawna, jak i nowo powstających tzw. wariantów społecznych. Publikacje

This is an Open Access article distributed under the terms of the Creative Commons Attribution 3.0 PL License (creativecommons.org/licenses/by/3.0/pl/), which permits redistribution, commercial and non-commercial, provided that the article is properly cited. () The Author(s) 2017. 
te nie tylko prezentują bowiem całościowo dany kod, lecz także wyznaczają pewien analityczny kanon, który może być powielany w badaniach socjolingwistycznych. Duża odpowiedzialność ciążyła więc z pewnością na Annie Niepytalskiej-Osieckiej, która w książce Socjolekt polskich alpinistów. Analiza leksykalno-semantyczna słownictwa (2014) przybliżyła czytelnikom dotychczas niezanalizowaną kompleksowo odmianę polszczyzny stanowiącą narzędzie porozumienia wśród wspinaczy górskich i grotołazów ${ }^{1}$.

Licząca niemal 300 stron monografia składa się z dwóch części zasadniczych, z których pierwsza ma charakter opisowo-analityczny (ss. 140), a drugą stanowi leksykon słownictwa alpinistycznego (ss. 120). Zamiast tradycyjnego wstępu opracowanie rozpoczyna półtorastronicowa cząstka zatytułowana Tematyka i cele opracowania, w której Autorka konkretyzuje przedmiot rozważań oraz zadania, jakie zamierza zrealizować. W kolejnych rozdziałach opisane zostają (2) teoretyczne podstawy analiz, (3) środowisko alpinistyczne, (4) przyjęte zasady metodologiczne, (5) warstwy leksykalne występujące w omawianym kodzie, (6-9) poszczególne grupy słownictwa (neologizmy, frazeologia, zapożyczenia wewnętrzne i obce), (10) międzywyrazowe związki znaczeniowe oraz (11) formy ekspresywne. Całość badaczka syntetyzuje w zwięzłym podsumowaniu. Uzupełniającymi elementami strukturalnymi są spis treści, wykaz bibliograficzny oraz ministreszczenie w języku angielskim. Konstrukcja pracy jest przemyślana i logiczna, a taki model kompozycyjny wydaje się optymalny dla opisu socjolektu. Można byłoby jedynie połączyć podrozdziały 3.2., 3.3. i 3.4., w których wątki historyczny, kulturowy i lingwistyczny wzajemnie się przeplatają. Wydzieliłabym również w osobnym rozdziale podejmowane przez Autorkę próby tematycznego uporządkowania zgromadzonej leksyki, gdyż prezentacja pól leksykalno-semantycznych mogłaby ułatwić czytelnikom poznanie tych fragmentów rzeczywistości, które są nazywane przez alpinistów w sposób swoisty.

Anna Niepytalska-Osiecka precyzuje, że jej podstawowym zamierzeniem „jest opis i analiza słownictwa wszystkich grup tworzących polskie środowisko wspinaczkowe, czyli alpinistów wspinających się w terenie wysokogórskim, alpinistów eksplorujących jaskinie (tzw. grotołazów) i wspinaczy skalnych" (Niepytalska-Osiecka, 2014, s. 13). Przyjmuje przy tym koncepcję Andrzeja Markowskiego wyodrębniającego w socjolektach dwie warstwy słownictwa:

${ }^{1}$ Książka stanowi zwieńczenie kilkuletnich badań Autorki (Niepytalska, 2010; Niepytalska-Osiecka, 2010). 
utożsamiającą (formy o identycznym znaczeniu w języku ogólnym) i wyróżniającą (leksyka swoista). Autorka zaznacza, że przedmiotem badań będzie drugi z wymienionych zbiorów, w którym wydziela leksykę wspólnq (właściwa dla całej zbiorowości wspinaczy) oraz odrębna (funkcjonująca w poszczególnych grupach alpinistów). Zapowiada też, że na podstawie analiz ustali proporcje między określeniami zawodowymi i ekspresywnymi, co pozwoli na usytuowanie omawianego kodu wśród innych odmian. $Z$ tego powodu $\mathrm{w}$ rozdziale teoretycznym rozpoczynającym właściwe rozważania badaczka sprawnie przybliża liczne koncepcje zróżnicowania polszczyzny oraz wybrane typologie socjolektów, wykazując się gruntowną wiedzą. Czasem można było jednak dołączyć do opisu odautorski komentarz. Trzeba też odnotować, że przydarzyły się - zapewne wskutek skrótów myślowych - drobne nieścisłości. W opisie klasyfikacji Aleksandra Wilkonia (2000) pominięto familekty, a to właśnie te warianty, nie zaś - jak sugeruje Niepytalska-Osiecka - wydzielone przez lingwistę psycholekty, odpowiadają wskazanemu przez Teresę Skubalankę stylowi rodzinnemu. Z kolei kategorie socjolektalne wyróżnione przez Stanisława Grabiasa (a nie Danutę Buttler) to nie konkretne socjolekty, a parametry współistniejące $\mathrm{w}$ różnych proporcjach $\mathrm{w}$ każdym slangu, profesjolekcie czy żargonie.

Czasem trudno ocenić, które z prezentowanych w książce ujęć klasyfikacyjnych stanowią element lingwistycznego światopoglądu Autorki. Stwierdza ona wprawdzie, że za Markowskim przyjmuje definicję odmiany leksykalnej, którą jest jego zdaniem socjolekt, a w odniesieniu do tych wariantów podziela teoretyczne poglądy Wilkonia i Grabiasa. Ta dość ogólna uwaga nie rozwiązuje problemu, gdyż ujęcia obu językoznawców nie są identyczne, a w niektórych punktach są wręcz rozbieżne. Ponadto nie uprawniają - jak pisze badaczka - do poprzestania na używaniu terminu socjolekt w odniesieniu do charakteryzowanego w książce kodu. Niekiedy lingwistka ostrożnie określa go też mianem odmiany środowiskowej (Niepytalska-Osiecka, 2014, s. 22), argumentując, że wspinaczy górskich nie łączy więź zawodowa. Na tej samej stronie zaznacza jednak, że w środowisku alpinistów funkcjonuje zarówno „grupa zawodowa, którą tworzą instruktorzy wspinaczki sportowej, zawodowi alpiniści [...], wspinacze wykorzystujący swoje umiejętności nabyte w górach do prac wysokościowych", jak i amatorzy (s. 22). W innym miejscu czytamy, że omawiany wariant jest niejako pograniczny, składa się bowiem ze słownictwa ekspresywnego i zawodowego. Wydaje się więc, że mamy tutaj do czynienia z pewną niekonsekwencją, jako że Autorka, klasyfikując opisywany przez siebie kod, raz 
bierze pod uwagę rodzaj więzi między jego użytkownikami, innym zaś razem charakter leksyki. Niepotrzebnie unika jednak jednoznacznych rozstrzygnięć, gdyż jej rzetelne analizy wyraźnie wykazują, że język alpinistów to profesjolekt. Dominują w nim bowiem formy odnoszące się do zjawisk profesjonalnych właśnie, stanowiących - nazwijmy to - „rzeczywistość wspinaczkową”, i fakt występowania amatorów w grupie alpinistów nie ma tu znaczenia.

Badaczka klarownie uzasadnia natomiast, dlaczego interesujące ją narzędzie komunikacji należy uznać za socjolekt, podkreślając m.in. stabilność grupy, silne więzi między członkami i poczucie odrębności. Za dodatkowy argument przyjmuje liczbę form swoistych, których zgromadziła ponad 740. Powołała się w tym miejscu na autorytet D. Buttler (1973) konstatującej, że w opisach wariantów środowiskowych $\mathrm{z}$ lat 70. XX w. funkcjonowało średnio 500-3000 leksemów. A. Niepytalska-Osiecka uznała na tej podstawie, że aby mówić o odrębnym kodzie, zasób słownictwa używanego przez daną zbiorowość musi przekraczać 500 określeń. O ile jest to zrozumiała próba oszacowania liczebności zbioru swoistych jednostek decydującej o istnieniu specyficznego wariantu, o tyle nie znajduję przekonujących argumentów, dlaczego właśnie liczba 500 powinna być graniczna.

W rozdziale poświęconym dziejom alpinizmu uwidacznia się znawstwo Autorki, która zdradza, że uprawia turystykę górską i zna analizowane słownictwo. Charakteryzując poszczególne zagadnienia, takie jak zakres znaczeniowy terminu alpinizm, etos wspinacza czy rozwój dyscypliny, badaczka powołuje się na fachową literaturę i specjalistyczne czasopisma. Sprawnie prowadzi wywód, inkrustując go gdzieniegdzie barwnymi wyimkami z pamiętników ludzi gór. Niektóre wątki wydają się jednak niepotrzebne, jak choćby ten o dopingu czy nadużywaniu alkoholu przez taterników podczas wspinaczki. Warto byłoby zamiast tego nawiązać do tzw. legendarnego alpinizmu (w tym do kontekstów „starożytnych”, zdobycia Mont Ventoux przez Petrarkę w 1336 r. czy Mont Aiguille przez francuskich najemników w 1492 r.) oraz granicznego 8 sierpnia 1786 r., kiedy to Jakub Balmat i Chaminix Michael Peccard zdobyli szczyt Mont Blanc, rozpoczynając w ten sposób erę nowoczesnego alpinizmu (Long, 2014; Roszkowska, 2013). Może udałoby się poprzez takie odniesienia precyzyjnej określić początki polskiego socjolektu wspinaczy, które Autorka datuje na przełom XIX i XX w. Za pierwszą turystkę tatrzańską uchodzi wszak Beata Łaska, która już w 1565 r. odbyła poświadczoną w źródłach wycieczkę górską. W pierwszej dekadzie XIX w. Stanisław Staszic poznawał podczas wędrówek Alpy i Apeniny, wszedł na Wezuwiusz i Etnę, a w polskich górach zdobył Krywań, 
Kołowy Szczyt oraz - jako pierwszy w historii - Łomnicę uważaną wówczas za najwyższy szczyt Tatr (Lewan, 2004; Roszkowa, 2013). Z kolei w 1818 r. poeta Antoni Malczewski zdobył Mont Blanc oraz Aiguille du Midi (Chwaściński, 1968). Te wszystkie fakty mogą sugerować, że historia profesjolektu opisywanego przez A. Niepytalską-Osiecką może być znacznie dłuższa.

Wysoko trzeba ocenić dobór źródeł, z których pozyskano materiał empiryczny. Autorka sięgnęła do licznych książek, przewodników i periodyków o tematyce górskiej, a także przewertowała zasoby wielu stron internetowych. Szkoda jedynie, że nie podano dokładnej liczby wykorzystanych egzemplarzy czasopism oraz nie określono, ile skompletowanych form pochodzi z poszczególnych źródeł. Badaczka dodaje też, że jako osoba uprawiająca turystykę górską gromadziła informacje leksykalne podczas obserwacji uczestniczącej, co nie tylko pozwalało na poznawanie kodu w okolicznościach naturalnych (w użyciu), lecz także umożliwiało podjęcie właściwych decyzji definicyjnych. Fakt posługiwania się opisywanym wariantem świadczy o kompetencjach uprawniających do jego opisu, choć niepokojące może być zdanie, w którym Autorka zaznacza, że w trakcie analiz „przede wszystkim polega[m] na własnej znajomości socjolektu alpinistycznego” (Niepytalska-Osiecka, 2014, s. 23). Może to bowiem rodzić pytania o obiektywizm i rzetelność w prezentowaniu odmiany. Wątpliwości te rozwiewa jednak zastosowanie klasycznego w pracach socjolingwistycznych rozwiązania polegającego na eksponowaniu form swoistych w konkretnych wypowiedziach. Taka metoda pozwala zweryfikować słuszność podawanych definicji oraz poznać zasady funkcjonowania wyrazu w żywej mowie. Można jedynie żałować, że w słowniczku przeważają konteksty współczesne. Ciekawsze moim zdaniem byłyby cytaty z publikacji z przełomu XIX i XX w., z których zaczerpnięto jedynie ok. 20 wyimków.

Biorąc pod uwage prace wydane w drugiej połowie XIX w. oraz w oparciu o informacje na temat historii alpinizmu, Autorka podjęła udaną próbę przedstawienia rozwoju opisywanego profesjolektu. Wśród ustalonych etapów kształtowania się tej odmiany znalazły się następujące fazy: wymieniona już (1) początkowa - przełom XIX i XX w., (2) lata 50. i 60. XX w., (3) okres „właściwy"- lata 70. i 80. ubiegłego stulecia oraz (4) najnowszy - przełom XX i XXI w. Taki podział jest przekonujący, choć można się zastanawiać, czy rzeczywiście typowy dla lat 70. i 80. rozwój alpinizmu oraz nasycenie formami fachowymi prasy specjalistycznej są wystarczającymi dowodami na to, że właśnie w tym czasie „ukształtował się socjolekt alpinistyczny” (Niepytalska-Osiecka, 2014, s. 41). Skoro ów kod rozwijał się wcześniej, to skąd wiadomo, że w latach 50. 
nie liczył magicznych 500 form, zwłaszcza że - jak pisze Autorka - już wówczas organizowano w Polsce alpiniadę tatrzańską? Nasycenie prasy o tematyce górskiej słownictwem fachowym może być pewną wskazówką, ale nie uznawałabym tego za bezwzględny wyznacznik. To, że jakieś określenie nie pojawiało się $\mathrm{w}$ periodykach, nie oznacza, że nie istniało i nie było używane. Z pewnością jednak nie da się dziś jednoznacznie opisać stanu socjolektu w XIX w., skoro dysponujemy tylko ograniczonym piśmiennictwem, a to powoduje, że konstruowanie prawdopodobnych scenariuszy jest zrozumiałe i konieczne. $\mathrm{Z}$ tego też powodu należy docenić zawartą w książce próbę opisu socjolektu w przekroju diachronicznym i oznaczenie w słowniczku archaicznych dziś jednostek kwalifikatorem przestarzały, co dodatkowo ilustruje przekształcenia omawianego wariantu.

Analiza materiału leksykalnego poświadcza umiejętności Autorki, która właściwie klasyfikuje i charakteryzuje zaobserwowane zjawiska językowe. Badaczka - co godne uznania - odważnie pisze o dylematach lingwistycznych. Nie obawia się pozostawienia bez rozstrzygnięcia chociażby problemów derywacyjnych w sytuacji, gdy możliwe są różne rozwiązania, a nie ma dostatecznych dowodów przemawiających za słusznością jednego z nich (np. różne hipotezy na temat pochodności wyrazów poręcz i poręczówka). Czasami można jednak dostrzec pewne niedostatecznie wyjaśnione kwestie. Lingwistka pisze m.in., że leksemy horolezka, mohutny i tabor zostały zapożyczone ze słowackiego, ale nie nadmieniła, że są to bohemizmy i że najciekawszy w tym zestawieniu jest rzeczownik horolezka dla polskich wspinaczy oznaczający plecak, w czeskim zaś desygnujący alpinistkę. Sądzę również, że należałoby przemyśleć kilka innych kwestii. Czy czasownik przyglebić rzeczywiście powstał od wyrazu gleba, czy może derywowano go od czasownika glebnąć? Czy skoro słowo puanieta/płanieta zostało utworzone od używanego również przez alpinistów francuskiego rzeczownika poignée [pư⿱㇒日勺 tego zapożyczenia na polskim gruncie? I czy skonstruowanie wspomnianej jednostki rzeczywiście obejmuje ucięcie podstawy słowotwórczej romanizmu? Są to oczywiście kwestie delikatne, może nawet niuanse, które z pewnością nie umniejszają wartości omawianej monografii.

Badaczka zaprezentowała ponadto związki semantyczne między jednostkami, opisując zjawiska synonimii i polisemii. Do zaproponowanych rozstrzygnięć nie można mieć zastrzeżeń i trzeba wyraźnie podkreślić staranność, z jaką Autorka łączyła formy w pary bliskoznaczne. Osobiście nie uznałabym jednak za synonimy dokładne leksemów o odmiennym 
nacechowaniu i różnych właściwościach gramatycznych (np. zacisk - cipa), choć uznani lingwiści przyjmują takie rozwiązania. Uzupełniłabym natomiast ten wątek o relacje antonimiczne (np. wkaszalny - niewkaszalny) oraz hiperonimiczno-hiponimiczne (np. asekuracja \{asekuracja dolna, asekuracja dynamiczna, asekuracja górna itd.\}).

Całość rozważań czytelnik otrzymuje w leksykograficznej pigułce w drugiej części książki. Opracowanie słownika wymagało dużej skrupulatności i pracowitości, wszak badaczka zamieszcza tam zgromadzone leksemy i opatruje je rozmaitymi informacjami dotyczącymi m.in. odmiany, składni czy etymologii. Do opisu wyrazów zastosowano różne kwalifikatory, w tym oficjalny i nieoficjalny, co może być problematyczne w kontekście przyjętej przez Autorkę koncepcji A. Markowskiego sytuującego odmiany środowiskowe i zawodowe wśród wariantów nieoficjalnych. Czy słownictwo oficjalne może bowiem występować w odmianie nieoficjalnej? Wydaje się, że taki podział leksyki nie jest zbyt funkcjonalny również z innego względu. Skoro oficjalne są terminy, a nieoficjalne są wszystkie pozostałe określenia, to może wystarczyłoby pierwszą grupę form oznaczyć zwyczajowo używanym w leksykografii kwalifikatorem terminologiczny, a pozostałe jednostki pozostawić bez oznaczeń? Sądzę też, że nie można stosować prostej odpowiedniości: oficjalny = zawodowy; nieoficjalny = niezawodowy. Mam bowiem wątpliwości, czy rzeczywiście wyrazy graniówka ('wspinaczka wzdłuż jednej lub kilku grani') lub zatopować ('dojść do szczytu drogi wspinaczkowej') są niezawodowe. Dotyczą one przecież fachowej rzeczywistości alpinistów, odnosząc się do rodzaju wspinaczki czy elementów jej realizacji. Autorka uznaje je natomiast za niezawodowe, biorąc pod uwagę, że stanowią one budulec komunikatów formułowanych podczas treningów czy prywatnych rozmów, nie zaś podczas samej wspinaczki. Moim zdaniem należałoby jednak uwzględniać znaczenie leksemu, nie zaś sytuacje, w których jest używany.

Trzeba podkreślić, że zbiór form omówionych w książce jest większy niż repertuar zawarty w słowniku. Nie pojawiły się w nim bowiem słowa, które zdaniem A. Niepytalskiej-Osieckiej wyszły już z użycia (np. akar, cassin, łojarz, triole). I o ile jej wiedzy i intuicji można zaufać, o tyle archaiczność jednostek nie powinna powodować nieuwzględniania ich w leksykonie. Omyłkowo pominięto też zwroty przyłożyć wektora i przełożyć niutona. Można żałować, że w słowniku nie zaznaczono interżargonowości leksemów funkcjonujących (najczęściej w różnych znaczeniach) w socjolektach lotniczym, motoryzacyjnym czy paralotniarskim, zwłaszcza że opatrzono kwalifikatorami geolo- 
giczny, turystyczny, młodzieżowy czy żeglarski określenia posiadające zbliżone znaczenie u alpinistów i innych grup społecznych. Uwypukliłoby to godne podziwu starania badaczki o przedstawienie międzyodmianowych związków słownych. Warto byłoby dodatkowo wymienić inne wyrazy, które funkcjonują $\mathrm{w}$ podobnym lub odmiennym znaczeniu w niewspomnianych $\mathrm{w}$ monografii odmianach, np. kaloryfer, motylek z profesjolektu kulturystów; bania, garnek z żargonu przestępczego; ekspres, łyżka stosowane przez myśliwych (Hoppe, 1981; Piekot, 2008; Stępniak, 1993).

Recenzowana książka wyróżnia się wysokim poziomem redakcyjnym, co niestety nie jest takie oczywiste we współczesnych pracach naukowych. Nie ma właściwie potknięć interpunkcyjnych, literówek, nieprawidłowo skonstruowanych adresów bibliograficznych czy niekonsekwentnie stosowanych wyróżnien. Wywód prowadzony jest w sposób klarowny i zrozumiały, choć pojawiło się kilka stylistycznych nieporadności (np. Ta ostatnia nazwa jest forma śnieżno-lodową, podczas gdy wszystkie opisane powyżej należa do struktur skalnych [Niepytalska-Osiecka, 2014, s. 105]). Poprawnie przygotowano wykaz bibliograficzny, liczący ok. 70 książek i 16 periodyków o tematyce alpinistycznej, 56 stron internetowych oraz 175 opracowań lingwistycznych i słowników. Taki zbiór imponuje, a de facto jest pokaźniejszy, gdyż nie uwzględniono wszystkich artykułów z czasopism przywoływanych w przypisach (np. Niepytalska-Osiecka, 2014, ss. 53-58, 60-62). Trzeba jednak wspomnieć, że w dużej mierze korzystano z publikacji klasycznych, choć dziś już odrobinę przestarzałych, o czym świadczy przybliżenie kategorii neologizmu głównie na podstawie prac wydanych w latach 60. i 70. XX w. Warto by uzupełnić literaturę o nowsze pozycje dotyczące chociażby socjolektów, w tym rozprawy Grażyny Sawickiej czy Tomasza Piekota. Wydaje się też, że wywód teoretyczno-analityczny zyskałby na przejrzystości, gdyby podawane informacje opatrywano odwołaniem bibliograficznym (w przypisach przywołano jedynie ok. $30 \%$ publikacji wynotowanych w spisie), choć być może o takim rozwiązaniu zadecydowały ograniczenia objętościowe.

Podsumowując, trzeba z całą mocą podkreślić, że książka Anny Niepytalskiej-Osieckiej to pierwsze w polskim piśmiennictwie lingwistyczne opracowanie profesjolektu alpinistycznego. Dotychczas pojawiały się tylko szkice prezentujące leksemy używane przez osoby uprawiające wspinaczkę górską czy eksplorujące jaskinie. Recenzowana monografia poszerza znacznie wiedzę na temat tego polskiego socjolektu mającego - jak się okazuje - ponadstuletnią historię na polskim gruncie. Zebrane przez Autorkę argumenty językowe i pozajęzykowe 
dowodzą, że ów kod jest specjalistycznym narzędziem, które z jednej strony gwarantuje skuteczną komunikację podczas wspinaczek, a $z$ drugiej warunkuje hermetyczność środowiska alpinistycznego. Co prawda w analizach pojawiają się pewne dyskusyjne rozstrzygnięcia, jednak wynikają one często $\mathrm{z}$ różnych koncepcji interpretacyjnych. Zawarte w niniejszym tekście uwagi to raczej wskazówki, uzupełnienia czy propozycje innych rozwiązań, które mogłyby zostać wykorzystane w dalszych badaniach nad socjolektem alpinistycznym. Na podstawie nowszych publikacji badaczki (Niepytalska-Osiecka, 2016) i dostępnych zasobów internetowych (Kuptz, 2000) można bowiem wnioskować, że ta odmiana polszczyzny szybko się rozwija i obfituje w formy, których w książce nie odnotowano (bambuła 'zaokrąglona skała', dno 'najniższy punkt jaskini', głaźnictwo 'wspinaczka po małych skałach’ itd.). Pomimo braku części określeń, którym naznaczone są wszystkie prace lingwistyczne, omawiana tu książka jest bez wątpienia wartościowa, jako że zawiera pokaźny zbiór form alpinistycznych i można jedynie żałować, że słownik nie został wydany jako oddzielna pozycja, mógłby on bowiem funkcjonować w szerszym obiegu. Trzeba też z zadowoleniem odnotować, że studium Anny Niepytalskiej-Osieckiej obok rozpraw o języku kulturystów (Piekot, 2008) czy profesjolekcie paralotniarzy (Pędzich, 2012) jest kolejnym opracowaniem nieopisanego dotąd wariantu o ograniczonym zasięgu społecznym. Wypada mieć nadzieję, że jest to początek kompleksowych badań nad polskimi socjolektami, które nie doczekały się jeszcze wieloaspektowej lingwistycznej deskrypcji.

\section{Bibliografia}

Buttler, D. (1973). Dyskusyjne zagadnienia opisu polskich gwar środowiskowych. W: B. Koneski, B. Vidoeski, \& K. Toshev (Red.), Govornite formi i slovenskite literaturni jazici (ss. 153-159). Skopje: Makedonska akademija na naukite i umetnostite.

Chwaściński, B. (1968). Narodziny alpinizmu polskiego. Taternik, (4), 154-159.

Hoppe, H. (1981). Słownik języka łowieckiego. Warszawa: Państwowe Wydawnictwo Naukowe.

Kuptz, J. (2000). Mały słownik slangu wspinaczkowo-jaskiniowego. Pobrano 25 lutego 2017, z http://www.sktj.pl/epimenides/szkol/slgnfr_p.html

Lewan, M. (2004). Zarys dziejów turystyki w Polsce. Kraków: Wydawnictwo „Proksenia”.

Long, S. (2014). Podręcznik wspinaczki górskiej (G. Kuc-Stefaniuk, Tłum.). Warszawa: Wiedza Powszechna.

Niepytalska, A. (2010). Funkcje słownictwa i frazeologii w gwarze środowiskowej wspinaczy skałkowych. Poradnik Językowy, (5), 25-36. 
Niepytalska-Osiecka, A. (2010). Zapożyczenia wewnętrzne w socjolekcie polskich alpinistów. W: B. Pędzich \& D. Zdunkiewicz-Jedynak (Red.), Polskie dźwięki, polskie słowa, polska gramatyka (system - teksty - norma - kodyfikacja) (ss. 407-415). Warszawa: Wydawnictwo Wydziału Polonistyki UW.

Niepytalska-Osiecka, A. (2014). Socjolekt polskich alpinistów: Analiza leksykalno-semantyczna słownictwa. Kraków: Wydawnictwo LIBRON - Filip Lohner.

Niepytalska-Osiecka, A. (2016). Najmłodsze słownictwo wspinaczkowe - najnowsze wpływy angielszczyzny na zasób leksykalny polskich wspinaczy. W: E. Wierzbicka-Piotrowska (Red.), Dialog pokoleń 2. Warszawa: Wydawnictwo Wydziału Polonistyki UW.

Pędzich, B. (2012). Jak powstaje socjolekt?: Studium słownictwa paralotniarzy. Warszawa: Wydawnictwo UW.

Piekot, T. (2008). Język w grupie społecznej: Wprowadzenie do analizy socjolektu. Wałbrzych: Wydawnictwo PWSZ im. Angelusa Silesiusa.

Roszkowska, E. (2013). Taternictwo polskie. Geneza i rozwój do 1914 roku. Kraków: AWF.

Stępniak, K. (1993). Słownik tajemnych gwar przestępczych. Londyn: Plus.

Wilkoń, A. (2000). Typologia odmian językowych współczesnej polszczyzny. Katowice: Wydawnictwo UŚ.

\section{Review: Anna Niepytalska-Osiecka, Socjolekt polskich alpinistów. Analiza leksykalno- semantyczna stownictwa, Wydawnictwo LIBRON - Filip Lohner, Kraków 2014, 286 pp.}

\section{Summary}

The article is a review of Anna Niepytalska-Osiecka's book Socjolekt polskich alpinistów. Analiza leksykalno-semantyczna słownictwa (The sociolect of Polish mountaineers. A lexical and semantic analysis of the vocabulary). First, the text summarizes the subject matter of this monograph, devoted to a hitherto undescribed variety of the Polish language. It then goes on to characterize the composition of the book and its methodology. Finally, some problematic points are indicated - concerning, among other things, the classification of the language variety analyzed or the development of its vocabulary - and alternative lexical and semantic solutions are suggested. 


\section{Rec.: Anna Niepytalska-Osiecka, Socjolekt polskich alpinistów. Analiza leksykalno- -semantyczna stownictwa, Wydawnictwo LIBRON - Filip Lohner, Kraków 2014, ss. 286}

\section{Streszczenie}

Artykuł stanowi recenzję książki Anny Niepytalskiej-Osieckiej pt. Socjolekt polskich alpinistów. Analiza leksykalno-semantyczna słownictwa. W tekście przybliżono zawartą w monografii problematykę poświęconą nieopisanemu dotychczas wariantowi polszczyzny oraz scharakteryzowano zastosowane rozwiązania kompozycyjne i analityczne. Wskazano również punkty dyskusyjne dotyczące m.in. klasyfikacji opisywanego wariantu polszczyzny czy procesu kształtowania się jego zasobu słownego, a także zasugerowano alternatywne rozstrzygnięcia leksykalno-semantyczne.

Keywords: review; sociolinguistics; sociolect; professiolect; professional language; sociolect of Polish mountaineers; mountaineering

Słowa kluczowe: recenzja; socjolingwistyka; socjolekt; profesjolekt; język zawodowy; socjolekt polskich alpinistów; alpinizm

\footnotetext{
Beata Jarosz, Institute of Polish Studies, Faculty of the Humanities, Maria Curie-Sklodowska University in Lublin Correspondence: beata.jarosz.1@wp.pl

This preparation of this article was financed with the statutory activities of the Institute of Polish Studies, Maria Curie-Sklodowska University in Lublin.

Competing interests: The author has declared she has no competing interests.
} 